\title{
SEBEZHETŐSÉGEK ÉS KOCKÁZAT VESZPRÉM MEGYÉBEN
}

\author{
Nagy Georgina, Domokos Endre \\ Pannon Egyetem, Környezetmérnöki Intézet, 8200 Veszprém, Egyetem utca 10., \\ e-mail: nagy.georgina@almos.uni-pannon.hu
}

\section{Összefoglaló}

Az éghajlatváltozás korunk egyik legmeghatározóbb kérdése, amely napjainkban már szemmel látható, érzékelhető formában jelentkezik a mindennapok során. Összetett hatásai folyamatosan gyorsuló ütemben fordulnak elö, ezzel nagyon kevés időt hagyva a mitigációs és az adaptációs intézkedéseknek. Kutatásunk középpontjában éppen ezért a sebezhetőségek és a kockázatok álltak. A kutatás mintaterületének Veszprém megyét választottuk. A megye éghajlata a viszonylag kis területi kiterjedése ellenére igen sokszínü. Különbözőek a besugárzási viszonyok, a hőmérsékleti kép, a vízháztartás és a csapadék területi eloszlása is. A megye levegőminőségét alapvetően az antropogén tevékenységekből származó kibocsátások határozzák meg, legnagyobb mértékben a gépipar és a vegyipar. Az elemzés során figyelembe vettük az emissziós és az immissziós értékeket is, azok alapján állapítottuk meg a megyében várható éghajlatváltozással kapcsolatos hatásokat. Kutatásunk elengedhetetlen részét képezték a globális éghajlati modellek úgy, mint az ALADIN-Climate és a RegCM klímamodell regionális szintü kiértékelése és összehasonlítása. Az eredmények alapján adaptációs intézkedési javaslatokat fogalmaztunk meg, figyelembe véve a dekarbonizációs és mitigációs intézkedéseket.

Kulcsszavak: éghajlatváltozás, légszennyezettség, klímamodellezés, mitigáció, adaptáció

\section{Bevezetés}

A tiszta levegö - mint a környezet alapvető alkotóeleme - elengedhetetlen a biztonságos és egészséges élethez, mivel az emberi test anyagcseréjének egyik mozgatórugója, amely nélkül az élet csak néhány percig fenntartható. A légkör és az abban lejátszódó folyamatok központi szerepet játszanak az emberek mindennapi életében, az üzleti és gazdasági tevékenységek mellett. A megnövekedett urbanizáció, motorizáció és iparosodás eredményeként a légkör egyre szennyezettebbé vált, melynek következtében a légszennyező anyagok koncentrációja meghaladta az egészségügyi határokat. Számos kutató a légszennyező anyagok térbeli eloszlását és időbeli tendenciáit is vizsgálta (Sharma \& Kulshrestha, 2014; Petracchini et al., 2016; Wu et al., 2011), amelyek meghatározzák az életminőséget, különösen az olyan nagyvárosokban, mint Párizs, Peking vagy New York (Masiol et al., 2017). Korábbi tanulmányok (Cuhadaroglu \& Demirci, 1997; Chelani \& Rao, 2013; Plaisance et al., 2004) arra is rámutattak, hogy a különféle légszennyező anyagok és a meteorológiai paraméterek között összefüggés található. A levegő minősége erősen függ az időjárási viszonyoktól, következésképpen érzékeny a klímaváltozásra (Jacob \& Winner, 2009). Az elmúlt évtizedekben számos átfogó tanulmány készült az éghajlatváltozás lehetséges troposzférára gyakorolt hatásainak előrejelzésére (például Johnson et al., 2001). Mivel az utóbbi évek egyik legmeghatározóbb kérdése a klímaváltozás és az ahhoz történő adaptáció lett, így a kutatásunk középpontjában is ez a témakör állt, különös tekintettel a sebezhetőségekre és a kockázatokra. 


\section{Vizsgált terület}

A kutatás mintaterületének Veszprém megyét választottuk. Noha a megye térbeli kiterjedése viszonylag kicsi, éghajlata igen változatos. Míg a magasabb területekre mérsékelten hüvös, mérsékelten nedves éghajlat jellemző, addig a megye déli, Balaton környéki területein mérsékelten meleg, mérsékelten száraz éghajlat az uralkodó. A csapadék térbeli eloszlása igen jelentős (650-800 mm). A legmagasabb csapadékmennyiséget a Bakony-hegység magasabb régióiban (Köris-hegy) mérték, míg a megye csapadékban legszegényebb területeit keleten találjuk (Sárrét). A napsütés órák száma viszonylag egységes, ami évente 1960-2000 óra között változik. Az uralkodó szélirány észak vagy északnyugat, és a szélsebesség átlagos értéke eléri a $3 \mathrm{~m} / \mathrm{s}$-ot (Dövényi, 2010). A megye gazdag természeti erőforrásokban és ásványkincsekben (barnaszén, bauxit, mangánérc, mészkő, dolomit, bazalt). Az erőforrásoknak köszönhetően a megyében jelentős az ipari tevékenység (1., 2. ábra). Ezen ásványi és energiaforrások kinyerése, szállítása és feldolgozása során azonban egy vagy több légszennyező anyag szintje folyamatosan meghaladja a megengedett határértékeket. A megye levegőminőségét elsősorban a gépipar és vegyipar határozza meg, amelynek fö tevékenysége mütrágyák és növényvédő szerek elöállítása (TÉRPORT $\left.{ }^{1}\right)$.

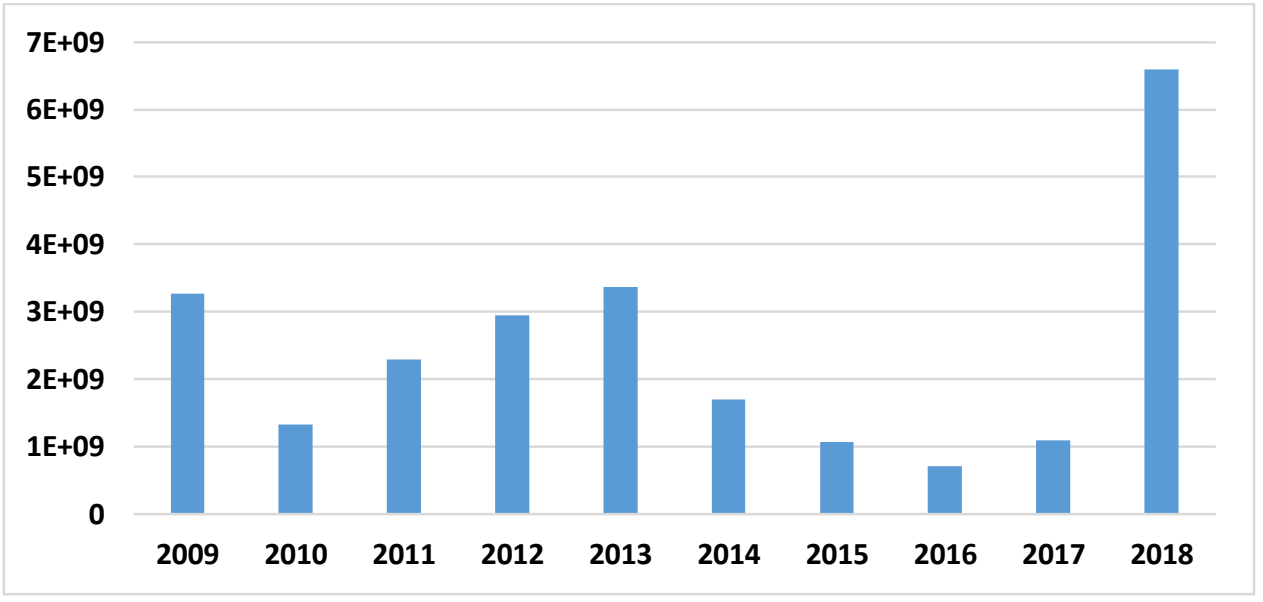

1. ábra: Veszprém megye szén-dioxid kibocsátásának alakulása [kg/év](Forrás: OKIR).

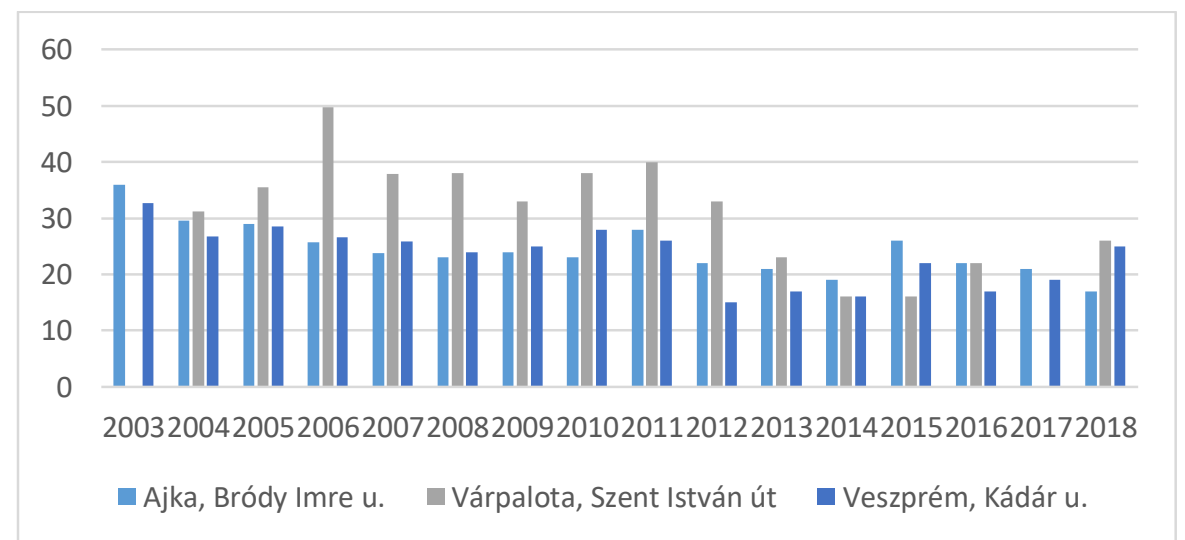

2. ábra: A levegő $10 \mu \mathrm{m}$ átmérő alatti szálló porral való szennyezettsége az automata mérőhálózat adatai alapján $\left[\mu \mathrm{g} / \mathrm{m}^{3}\right]$ (Forrás: OLM).

\footnotetext{
${ }^{1}$ TÉRPORT: http://www.terport.hu/megyek/magyarorszag-megyei/veszprem-megye
} 


\section{Klímamodellek}

A klímamodellek (ALADIN-Climate, RegCM) a Magyar Földtani és Geofizikai Intézet által üzemeltetett Nemzeti Alkalmazkodási Térinformatikai Rendszer (NaTéR) segítségével készültek el, különös figyelmet fordítva a 2021-2050 és 2071-2100 intervallumokban várható klímaváltozás hatásaira. A klímamodellek alapján a megyében $1,5-2{ }^{\circ} \mathrm{C}$-os hőmérséklet emelkedés várható 2050 -ig, ami 2100 -ra a $3,5^{\circ} \mathrm{C}$-ot is elérheti. A forró napok számában a két modell jelentősen eltér egymástól. Az ALADIN-Climate szerint 2100-ra akár 30 nappal is nöhet az ilyen napok száma (3. ábra).

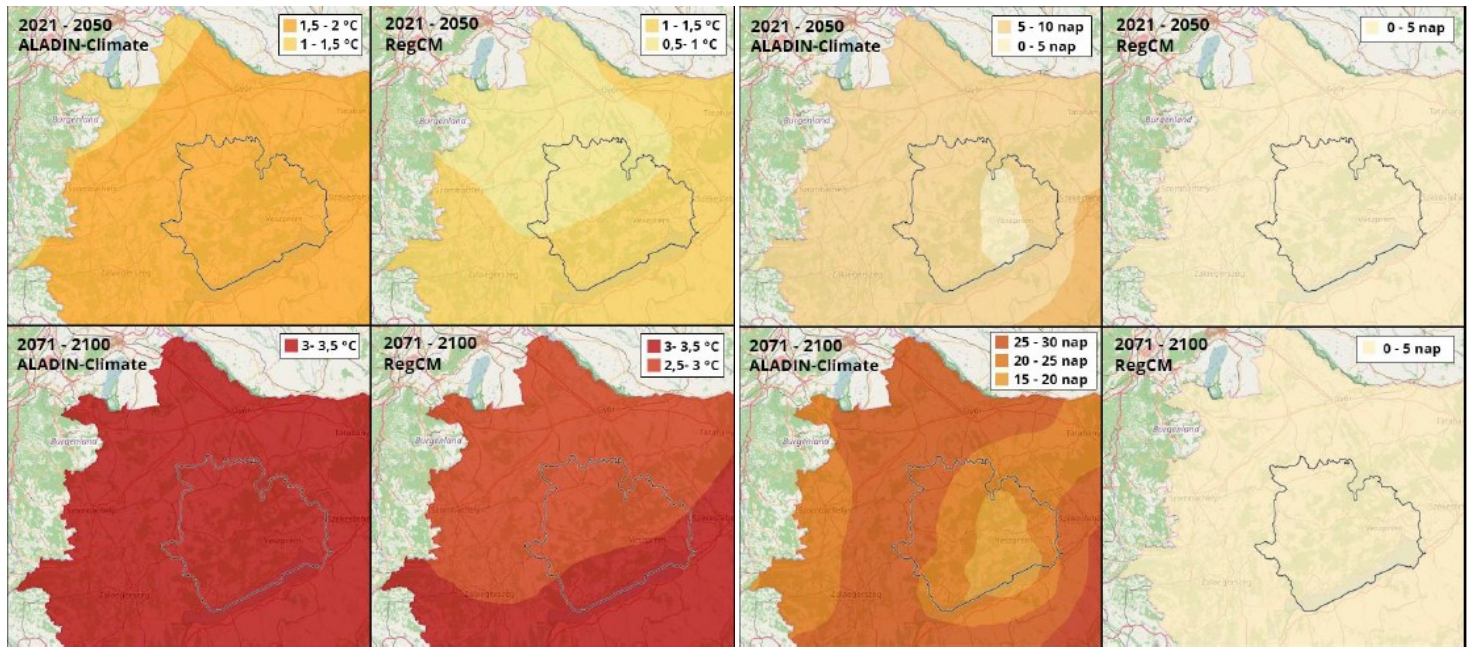

3. ábra: Balra a várható átlaghőmérséklet változása; jobbra a forró napok számának várható változása 2021-2050, valamint 2071-2100 között.

$\mathrm{Az}$ átlagos éves csapadékösszeg várható változása szintén eltérö mértéket mutat. $\mathrm{Az}$ ALADIN-Climate modell alapján kismértékü csökkenés lesz tapasztalható, míg a RegCM szerint nagymértékü növekedés lesz várható. A $30 \mathrm{~mm}-\mathrm{t}$ meghaladó csapadékos napok számának kismértékü (0-1 nap) növekedésében mindkét modell megegyezett (4. ábra).

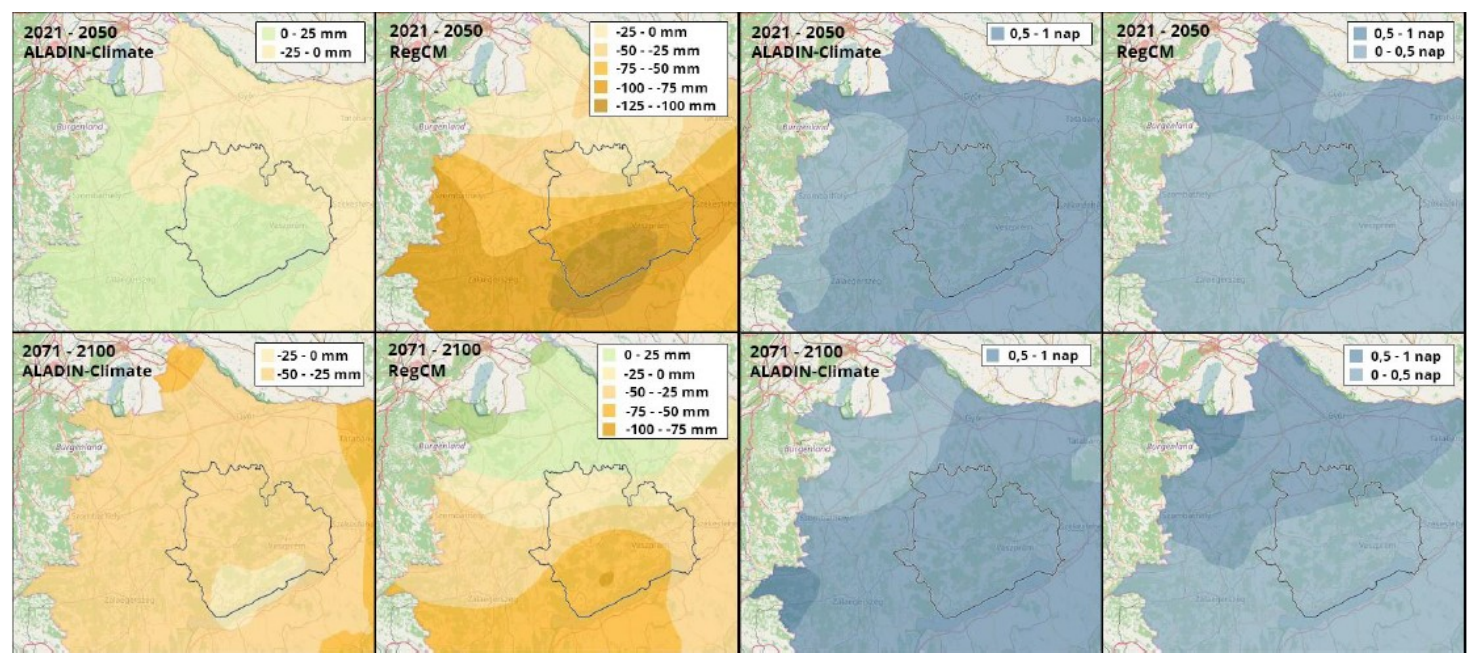

4. ábra: Balra csapadék várható változása; jobbra a 30 mm-t meghaladó csapadékos napok számának várható változása 2021-2050, valamint 2071-2100 között. 


\section{Éghajlatváltozás várható hatásai}

A klímamodellek eredményei alapján meghatároztuk a megyében várható, éghajlatváltozással leginkább érintett területeket (1. táblázat), melyek közül a természeti értékek, az agrárium illetve turizmus a legveszélyeztetettebbek. A megye természeti értékei közül az élővilágra elsősorban az emelkedő hőmérséklet és a szélsőséges időjárási események előfordulásának növekedése jelent veszélyt. Az agrárgazdaságra, különös tekintettel a borászatra, a veszélyt a növekvő aszály jelenti. Az egyre gyakoribb hőhullámok, erősödő UV sugárzás, valamint az extrém időjárási jelenségek kedvezőtlenül érinthetik a Balatont, s rajta keresztül a turizmust $\mathrm{s}$ a megyét is.

1. táblázat: Éghajlatváltozáshoz köthetö veszélyek és azok kockázatai a megyében.

\begin{tabular}{|l|l|l|}
\hline \multicolumn{1}{|c|}{$\begin{array}{c}\text { Éghajlattal } \\
\text { kapcsolatos veszély } \\
\text { típusa }\end{array}$} & \multicolumn{1}{|c|}{ Várható hatások } & \multicolumn{1}{|c|}{$\begin{array}{c}\text { Aktuális veszélyforrásból } \\
\text { eredö kockázat foka }\end{array}$} \\
\hline Villámárvíz & $\begin{array}{l}\text { nagy mennyiségü lokális csapadék rövid idő alatti } \\
\text { lehullása következtében a kisvízfolyásokon } \\
\text { kialakuló árvizek }\end{array}$ & Magas \\
\hline Ivóvízbázisok & $\begin{array}{l}\text { csökkenő vízkészletek és növekvő vízigény, } \\
\text { árvizek, karsztárvizek esetén kialakuló vízminőség- } \\
\text { romlás }\end{array}$ & Magas \\
\hline Természeti értékek & $\begin{array}{l}\text { biológiai sokféleség csökkenése, invazív fajok } \\
\text { elöretörése }\end{array}$ & Magas \\
\hline Viharok & katasztrófa helyzetek számának növekedése & Magas \\
\hline Erdőtüz & „száraz erdő” spontán tüzek & Mérsékelt \\
\hline Szélsőséges hideg & $\begin{array}{l}\text { fagyos napok számának csökkenése, } \\
\text { mezőgazdasági termelékenység csökkenése }\end{array}$ & Mérsékelt \\
\hline Aszály & agrárgazdasági terméskiesés (növénytermesztés) & Mérsékelt \\
\hline
\end{tabular}

A kockázatok és sebezhetőségek elemzését követően a megyében várható hatásokat határoztuk meg az érintett szakpolitikai ágazatok, bekövetkezések valószínüsége, illetve a hatások foka alapján (2. táblázat).

2. táblázat: Éghajlatváltozással érintett szakpolitikai ágazatok és az ágazatokban várható hatások.

\begin{tabular}{|c|c|c|}
\hline $\begin{array}{l}\text { Érintett szakpolitikai } \\
\text { ágazat }\end{array}$ & Várható hatások & Hatás várható foka \\
\hline Épületek & állagromlás & Mérsékelt \\
\hline Közlekedés & $\begin{array}{l}\text { közlekedési infrastruktúra károsodása: útburkolat } \\
\text { töredezés, festés lekopik, kiporzás, gépjármü } \\
\text { minőség romlása }\end{array}$ & Magas \\
\hline Energia & $\begin{array}{l}\text { energiaellátási infrastruktúra és az áramtermelő } \\
\text { létesítmények károsodása: áramkimaradás, } \\
\text { áramszünet }\end{array}$ & Mérsékelt \\
\hline Hulladékgazdálkodás & $\begin{array}{l}\text { hulladék feldolgozó, kezelö létesítmények, } \\
\text { eszközök károsodása }\end{array}$ & Mérsékelt \\
\hline Vízgazdálkodás & vízhiány, aszályos napok számának emelkedése & Magas \\
\hline $\begin{array}{l}\text { Mezőgazdaság és } \\
\text { erdészet }\end{array}$ & $\begin{array}{l}\text { terméshozam hanyatlása, állattartás hanyatlása, } \\
\text { termelékenység hanyatlása }\end{array}$ & Magas \\
\hline Turizmus & $\begin{array}{l}\text { vízparti, téli és városlátogató desztinációk } \\
\text { veszélyeztetettsége, idegenforgalmi visszaesés }\end{array}$ & Mérsékelt \\
\hline
\end{tabular}




\section{Lehetőségek}

A megyében jelentkező és várható klímaváltozással kapcsolatos akadályok megoldásához elsősorban a veszélyek és az erősségek azonosítása a fontos. Ehhez nyújt segítséget a megye több stratégiája is, többek között Veszprém megye klímastratégiája, Veszprém MJV Fenntartható Klíma és Energia Akcióterve, illetve a megyében található városok környezetvédelmi programjai is. A stratégiák mellett elengedhetetlen a lehetőségek kiaknázása, a megújuló energia potenciál nagyobb mértékü kihasználása, csapadékvíz visszatartás lehetősége, illetve a szürkevíz hasznosítás is. A dekarbonizációs célok eléréséhez viszont nélkülözhetetlen a lakosság bevonása, ezért kiemelt figyelmet kell szentelni az energia- és klímatudatossági szemléletformálási programoknak, illetve a civil kezdeményezéseknek és szervezeteknek.

\section{Hivatkozások}

Chelani, A.B., Rao, P.S., 2013: Temporal variations in surface air temperature anomaly in urban cities of India. Meteorol Atmos Phys, 121: 215-221. https://doi.org/10.1007/s00703-013-0262-8

Cuhadaroglu, B., Demirci, E., 1997: Influence of some meteorological factors on air pollution in Trabzon city. Energy and Buildings, 25: 179-184. https://doi.org/10.1016/S03787788(96)00992-9

Dövényi, Z. [szerk], 2010: Magyarország kistájainak katasztere. 2., átdolgozott kiadás. MTA FKI, Budapest.

Jacob, D.J., Winner, D.A., 2009: Effect of climate change on air quality. Atmos Environ., 43(1): 51-63. https://doi.org/10.1016/j.atmosenv.2008.09.051

Johnson, C.E., Stevenson, D.S., Collins, W.J., Derwent, R.G., 2001: Role of climate feedback on methane and ozone studied with a coupled ocean-atmosphere-chemistry model. Geophys Res Lett., 28(9): 1723-1726. https://doi.org/10.1029/2000GL011996

Masiol, M., Hopke, P.K., Felton, H.D., Frank, B.P., Rattigan, O.V., Wurth, M.J., LaDuke, G.H.,2017: Analysis of major air pollutants and submicron particles in New York City and Long Island. Atmospheric Environment, 148: 203-214.

https://doi.org/10.1016/j.atmosenv.2016.10.043

Petracchini, F., Paciucci, L., Vichi, F., D'Angelo, B., Aihaiti, A., Liotta, F., Paolini, V., Cecinato, A., 2016: Gaseous pollutants in the city of Urumqi, Xinjiang: spatial and temporal trends, sources and implications. Atmospheric Pollution Research, 7(5): 925-934. ISSN 1309-1042. https://doi.org/10.1016/j.apr.2016.05.009

Plaisance, H., Piechocki-Minguy, A., Garcia-Fouque, S., Galloo, J.C., 2004: Influence of meteorological factors on the NO2 measurements by passive diffusion tube. Atmospheric Environment, 38: 573-580. https://doi.org/10.1016/j.atmosenv.2003.09.073

Sharma, D., Kulshrestha, U.C., 2014: Spatial and temporal patterns of air pollutants in rural and urban areas of India. Environmental Pollution, 195: 276-281. https://doi.org/10.1016/j.envpol.2014.08.026

Wu, C., Liu, S. L-J.,Cullen, A., Westberg, H., Williamson, J., 2011: Spatial-temporal and cancer risk assessment of selected hazardous air pollutants in Seattle. Environment International, 37(1): 11-17. https://doi.org/10.1016/j.envint.2010.06.006

\section{Internetes hivatkozások}

TÉRPORT: http://www.terport.hu/megyek/magyarorszag-megyei/veszprem-megye 